Jurnal Maksipreneur:
Manajemen, Koperasi, dan Entrepreneurship $\quad$ Vol. 11 No. $1 \quad$ Desember $2021 \quad$ hal. $90-104$

\title{
Pengaruh Personal Attitude dan E-learning terhadap Minat Berwirausaha pada Era Pandemi Covid-19
}

\author{
Shita Lusi Wardhani \\ Manajemen, STIE YKPN Yogyakarta, Indonesia \\ Manggar Wulan Kusuma \\ Akuntansi, STIE YKPN Yogyakarta, Indonesia \\ Korespondensi penulis: lusi.wardhani@gmail.com
}

\begin{abstract}
The Covid-19 outbreak and the enactment of restrictions on community activities have had many impacts, one of which is the change in teaching methods from offline learning or face-to-face activities to online learning or distance learning. These changes can affect the learning process, especially subjects related to business practices, such as entrepreneurship. In online learning, several factors contribute to the successful delivery of online courses. However, little is known about the impact of these factors on Indonesian students' interest in entrepreneurship. Therefore, the purpose of this study was to examine the effect of personal attitude and e-learning on interest in entrepreneurship in the Covid19 pandemic era. Data was collected through an online survey of 190 students who were taking entrepreneurship courses at selected universities in Yogyakarta. Data collected through online surveys were analyzed using Smart Partial Least Square (SmartPLS) 3.0. The results of this study found that interest in entrepreneurship is significantly influenced by personal attitude and e-learning. This study also found that perceived learning was not able to moderate the effect of e-learning on entrepreneurial interest.
\end{abstract}

Keywords: E-learning; Entrepreneurial interest; Entrepreneurship education; Perceived learning; Personal attitude.

Abstrak. Wabah Covid-19 dan berlakunya pembatasan kegiatan masyarakat telah membe-
rikan banyak dampak perubahan. Salah satu dampak tersebut adalah perubahan metode
pengajaran di lembaga pendidikan dari pembelajaran offline atau kegiatan tatap muka
menjadi pembelajaran online atau pembelajaran jarak jauh. Perubahan tersebut dapat
mempengaruhi proses pembelajaran, khususnya mata mahasiswaan yang berkaitan dengan
praktik bisnis, seperti kewirausahaan. Dalam pembelajaran online, beberapa faktor ber-
kontribusi terhadap keberhasilan penyampaian mata mahasiswaan online. Namun, belum
banyak pengetahuan tentang dampak faktor-faktor tersebut terhadap minat berwirausaha
peserta didik di perguruan tinggi Indonesia. Oleh karena itu, tujuan penelitian ini adalah
menguji pengaruh personal attitude dan e-learning terhadap minat berwirausaha mahasis-
wa dan peran moderasi perceived learning di lembaga pendidikan tinggi di Indonesia. Data 
dikumpulkan melalui survei online terhadap 190 mahasiswa yang sedang menempuh mata kuliah kewirausahaan di perguruan tinggi terpilih di Yogyakarta. Data yang telah dikumpulkan melalui survei online tersebut dianalisis menggunakan Smart Partial Least Square (SmartPLS) 3.0. Hasil penelitian ini menemukan bahwa minat berwirausaha secara signifikan dipengaruhi oleh personal attitude dan e-learning. Penelitian ini juga menemukan bahwa perceived learning tidak mampu memoderasi pengaruh e-learning terhadap minat berwirausaha.

Kata kunci: E-learning; Minat berwirausaha; Pendidikan kewirausahaan; Perceived learning; Personal attitude.

\section{Article Info:}

Received: January 16, $2021 \quad$ Accepted: August 11, 2021

Available online: August 23, 2021

DOI: http://dx.doi.org/10.30588/jmp.v11i1.782

\section{LATAR BELAKANG}

Keputusan kebijakan pembatasan kegiatan masyrakat yang diumumkan oleh pemerintah Indonesia sebagai akibat pandemi Covid 19 telah memberikan dampak cukup besar terutama di bidang ekonomi. Pandemi COVID 19 setidaknya memberikan tiga dampak terhadap perekonomian Indonesia, yaitu melemahnya daya beli, menimbulkan ketidapastian di bidang investasi, dan penurunan komoditas (Fikri, 2021). Untuk mengatasi hal tersebut, pemerintah perlu mendorong para akademisi di perguruan tinggi mampu menciptakan wirausahawan maupun konsultan bisnis Usaha Mikro, Kecil, dan Menengah (UMKM) atau Usaha Kecil dan Menengah (UKM) untuk menciptakan lapangan kerja yang lebih luas.

Untuk menjawab tantangan terkait penciptaan wirausahawan dan konsultan bisnis tersebut, perguruan tinggi berperan penting dalam mempersiapkan lulusan sebagai tenaga kerja yang memiliki perspektif dan kemampuan kewirausahaan. Sebagian besar perguruan tinggi telah menunjukkan usaha tersebut dengan menyelenggarakan kurikulum berbasis kewirausahaan (Rifa'i \& Nugraha, 2019). Proses pembelajaran yang semula dilakukan dengan porsi teori lebih banyak, saat ini berubah menjadi proses pembelajaran yang menyeimbangkan antara teori dan praktik. Namun, kebijakan pembatasan kegiatan masyarakat mengakibatkan proses pembelajaran menjadi sangat terbatas. Perguruan tinggi terpaksa mengubah metode pembelajarannya menjadi pertemuan secara online. Sekitar $98 \%$ perguruan tinggi di Indonesia melakukan pembelajaran daring akibat pandemi Covid 19 (CNN Indonesia, 2020). Kondisi tersebut mengakibatkan porsi pembelajaran praktik menjadi sangat terbatas. Salah satu akibat yang dikhawatirkan dari kegiatan kuliah online adalah proses pemunculan minat untuk menjadi wirausahawan menjadi kurang efektif. Hal itu dikarenakan pengajar tidak bisa secara langsung berinteraksi dengan mahasiswa dan mahasiswa memiliki kesempatan yang sangat terbatas untuk mendapatkan pengalaman berwirausaha.

Personal attitude merupakan evaluasi yang dilakukan oleh individu, baik secara positif atau pun negatif terhadap suatu benda, orang, institusi, perilaku, kejadian, atau minat 
tertentu (Ajzen \& Fishbein, 2005). Berdasarkan pendapat tersebut, personal attitude yang diharapkan muncul di dalam diri mahasiswa kewirausahaan dapat membentuk minat berwirausaha pada dirinya. Menurut Ajzen dan Fishbein (2005) dalam Theory of Planned Behavior, seseorang yang memiliki keyakinan tinggi untuk berperilaku tertentu akan mengarahkan pada hasil yang positif dan sikap favorable terhadap perilaku yang dimilikinya. Jadi, ketika mahasiswa memiliki minat kuat menjadi wirausahawan, maka ia akan membentuk perilaku wirausahawan di dalam dirinya. Di dalam kelas kewirausahaan, mahasiswa mempraktikkan cara mendirikan dan menjalankan sebuah usaha. Kegiatan praktik merepresentasikan hakikat mata kuliah yang didominasi kegiatan praktik, termasuk kewirausahaan. Namun, munculnya pandemi Covid 19 seakan mengharuskan pembelajaran kewirausahaan pun diadakan secara online. Hal ini menimbulkan kekhawatiran terhadap menurunnya motivasi mahasiswa berwirausaha (perceived learning). Hal tersebut akan berdampak pada berkurangnya minat mereka menjadi wirausahawan.

Banyak penelitian sebelumnya yang menyoroti kebutuhan dan tantangan dalam membangun minat berwirausaha peserta didik. Shane, Locke, dan Collins (2003) berpendapat bahwa membangkitkan minat berwirausaha pada seorang siswa membutuhkan waktu yang lama dan memiliki sejumlah tantangan tersendiri. Mahasiswa yang memiliki minat berwirausaha umumnya mengikuti mata kuliah kewirausahaan untuk memajukan ilmunya. Selain itu, Fiet (2002) dan Seagal, Borgia, Schoenfeld (2005) sepakat menyatakan bahwa pendidikan mampu meningkatkan ketrampilan kewirausahaan peserta didik melalui pemberian pengalaman penguasaan, disiplin, persuasi sosial, dan dukungan. Ketrampilan tersebut dapat diperoleh dengan melibatkan siswa secara langsung dalam kegiatan pembelajaran, menyusun rencana usaha, dan melakukan simulasi usaha kecil di dalam kelas berdasarkan metode pembelajaran konvensional.

Kursus ketrampilan kewirausahaan selalu dikaitkan dengan praktik bisnis. Pembelajaran online juga dapat mempengaruhi kualitas penyampaian materi praktik bisnis. Cristian dan Petronela (2012) membuktikan bahwa pendidikan kewirausahaan di Rumania menggunakan e-learning sebagai alat yang efisien untuk mengajarkan kewirausahaan dan menemukan beberapa proyek yang dirancang untuk memenuhi kebutuhan pendidikan kewirausahaan masyarakat perdesaan untuk membuat mereka mampu memanfaatkan peluang bisnis lokal. Ketidakefektifan penyampaian materi tentang kewirausahaan atau praktik berwirausaha akan mempengaruhi proses belajar peserta didik, sehingga hal itu dapat mempengaruhi minat berwirausaha mereka. Cara seseorang menerima materi mata kuliah kewirausahaan diharapkan dapat mempengaruhi hubungan antara penyelenggaraan kuliah kewirausahaan yang dilakukan secara online terhadap minatnya untuk berwirausaha. Oleh karena itu, perceived learning dapat menjadi faktor yang memoderasi pengaruh $e$-learning terhadap minat berwirausaha.

Beberapa literatur menunjukkan bahwa penelitian terdahulu lebih fokus kepada pemeriksaan faktor-faktor yang mempengaruhi efektivitas $e$-learning terhadap minat berwirausaha dengan perceived learning sebagai variabel moderasi. Ansong, Boateng, Boateng, dan Effah (2016) mengkaji dampak teknologi, organisasi, dan lingkungan terhadap $e$ learning dan pembelajaran yang dipersepsikan. Dalam penelitian tersebuti, penerapan $e-$ learning secara tiba-tiba seperti yang terjadi pada kondisi pandemi Covid-19 dapat diang- 
gap sebagai perubahan instan yang terjadi pada proses pembelajaran di kelas menjadi penerapan e-learning. Oleh karena itu, tujuan penelitian ini adalah menguji pengaruh personal attitude dan e-learning terhadap minat berwirausaha mahasiswa dan peran moderasi perceived learning di lembaga pendidikan tinggi di Indonesia.

\section{KAJIAN TEORITIS}

\section{Pendidikan Kewirausahaan}

Menurut Tong, Tong, dan Loy (2011), pendidikan kewirausahaan adalah sebuah proses transmisi pengetahuan dan ketrampilan kewirausahaan kepada mahasiswa untuk membantu mereka mengeksploitasi kesempatan bisnis. Pendidikan kewirausahan juga merupakan sebuah upaya internalisasi jiwa dan mental kewirausahaan, baik melalui institusi pendidikan maupun institusi lain, seperti lembaga pelatihan (training) dan sebagainya (Wibowo, 2011). Tong et al. (2011) menjelaskan bahwa pendidikan kewirausahaan memiliki lima komponen, yaitu: know-what (pengetahuan berwirausaha), know-why (nilai dan motivasi), know-who (interaksi sosial), know-how (kemampuan berwirausaha), dan knowwhen (waktu yang tepat untuk berwirausaha). Asih, Kamil, dan Indrapriyatna (2020) berpendapat bahwa perguruan tinggi memiliki peran untuk mendorong mahasiswa agar berminat menjadi seorang pengusaha, sehingga mereka dapat membuka lapangan pekerjaan dan membantu mengurangi angka pengangguran. Dalam rangka mewujudkan hal tersebut, maka perguruan tinggi berperan penting untuk memberikan ilmu pengetahuan kewirausahaan melalui mata kuliah kewirausahaan dan menghasilkan sumber daya manusia (SDM) yang memiliki kompetensi yang baik dan berkualitas (Asih et al., 2020).

\section{Minat Berwirausaha}

Ajzen \& Fishbein (2005) menyebutkan bahwa individu cenderung memiliki minat terlebih dulu untuk memunculkan perilaku terhadap apa yang ia minati, sehingga individu tersebut merasa memiliki rasa untuk meningkatkan minat atau intensi tertentu. Krueger (1993) juga berpendapat bahwa minat berwirausaha merupakan komitmen individu dalam memulai usaha baru dan perlu mendapatkan perhatian dalam memahami proses pendirian usahanya yang baru. Dalam penelitian yang dilakukan oleh Lee dan Wong (2004) menunjukkan bahwa minat berwirausaha (entrepreneurial interest) merupakan suatu langkah awal dalam melakukan usaha yang biasanya bersifat jangka panjang. Mustofa (2014) berpendapat bahwa minat berwirausaha timbul karena adanya perasaan senang dan minat untuk menjalankan sebuah usaha. Indikator bahwa seseorang memiliki minat berwirausaha menurut Suryana dan Bayu (2014) adalah adanya perasaan senang dan memiliki perhatian khusus terhadap wirausaha.

\section{Personal Attitude}

Menurut Ismail dan Zain (2008), sikap atau attitude berasal dari bahasa Latin, yaitu aptus yang memiliki makna sesuai atau cocok dan siap untuk bertindak sesuatu. Ajzen \& Fishbein (2005) berpendapat bahwa sikap adalah evaluasi individu, baik secara positif atau negatif terhadap suatu benda, orang, institusi, perilaku, kejadian, atau minat tertentu. Berdasarkan Theory of Planned Behavior, seseorang yang memiliki keyakinan tinggi untuk ber- 
perilaku tertentu akan mengarahkan pada hasil yang positif dan sikap favorable terhadap perilaku yang dimilikinya, sedangkan seseorang yang percaya bahwa perilaku akan mengarahkan pada hasil yang negatif akan mengakibatkan orang tersebut memiliki sikap unfavorable (Ajzen \& Fishbein, 2005).

Personal attitude dapat diartikan sebagai sikap yang ditunjukkan oleh seorang individu, sejauh mana individu tersebut memegang penilaian pribadi yang positif atau negatif tentang menjadi seorang pengusaha. Pendidikan kewirausahaan tidak hanya memberikan landasan teori bagi konsep kewirausahaan, tetapi hal tersebut juga membentuk sikap, perilaku, dan pola pikir seorang pengusaha. Sikap, perilaku, dan minat berwirausaha pada seorang mahasiswa dapat dipengaruhi oleh pertimbangan berbagai aspek pilihan karir sebagai wirausaha. Minat berwirausaha telah dianggap sebagai elemen kunci untuk memahami proses penciptaan perusahaan baru (Bird, 1988). Personal attitude mahasiswa yang sedang mengikuti mata kuliah kewirausahaan dapat mempengaruhi minat berwirausaha pada diri mahasiswa tersebut. Ajzen dan Fishbein (2005) mengemukakan tentang Theory of Planned Behavior yang menyatakan bahwa personal attitude memiliki pengaruh terhadap minat seseorang yang diwujudkan dalam perilakunya. Penelitian oleh Ferreira, Raposo, Rodrigues, Dinis, dan do Paco (2012) membuktikan bahwa personal attitude berpengaruh positif terhadap minat berwirausaha. Berdasarkan uraian tentang berbagai indikator meliputi keuntungan sebagai wirausaha, wirausaha sebagai karir, kemampuan memulai usaha, kepuasan wirausaha, dan minat berwirausaha, maka hipotesis kesatu (H1) dirumuskan sebagai berikut:

\section{H1: Personal attitude berpengaruh terhadap minat berwirausaha.}

\section{E-Learning}

Menurut Zinn (2003), proses pembelajaran pada e-learning mengacu pada penggunaan komputer untuk menyajikan latihan dan tutorial kepada peserta didik dan melibatkan mereka dalam dialog tentang substansi pengajaran suatu mahasiswaan. Pandemi Covid-19 yang melanda hampir seluruh bagian dunia saat ini mengakibatkan setiap penyelenggaraan proses pembelajaran dilaksanakan secara online, termasuk pendidian maupun pelatihan kewirausahaan. Hal ini didukung oleh penelitian yang dilakukan oleh Cristian dan Petronela (2012) yang menyatakan bahwa proses pembelajaran e-learning yang dilakukan di Rumania merupakan sarana yang efisien untuk melakukan pembelajaran kewirausahaan sedangkan penelitian oleh Thompson dan Randall (2001) juga membuktikan bahwa internet telah membawa perubahan besar dalam kehidupan manusia, termasuk berbagai perubahan yang terjadi dalam proses pendidikan dan pembelajaran. Munculnya e-learning merupakan salah satu contoh perubahan yang terjadi. Proses pembelajaran dengan metode tradisional (offline) yang semula diyakini sebagai metode pembelajaran paling efektif telah berubah secara drastis.

E-learning diyakini mampu mengurangi, bahkan menghilangkan kendala geografis, budaya, dan logistik yang telah lama ada dalam penyelenggaraan pendidikan tradisional. Namun, hal-hal yang perlu diperhatikan agar proses pembelajaran e-learning ini dapat berjalan efektif adalah kewaspadaan terhadap berbagai permasalahan yang dapat muncul, 
seperti penggunaan dan pendistribusian materi pembelajaran, disain kegiatan pembelajaran berbasis internet, dan ketersediaan fasilitas jaringan internet. Proses pembelajaran online tidak semudah yang dibayangkan dan dilakukan oleh peserta didik. Banyak faktor yang mempengaruhi keefektifan hasil belajar online, khususnya proses pembelajaran mata kuliah Kewirausahaan. Hal tersebut dikarenakan untuk mendapatkan hasil belajar yang efektif dalam mata kuliah ini perlu adanya interaksi langsung antara pengajar dan peserta didiknya, peserta didik dan rekan sesama peserta lainnya, serta peserta didik dan masyarakat (sebagai konsumen) pada saat praktik kewirausahaan dilaksanakan. Dengan adanya sistem pembelajaran praktik kewirausahaan secara online, maka muncul pertanyaan apakah sistem pembelajaran e-learning dapat mempengaruhi minat peserta didik menjadi wirausaha. Berdasarkan uraian tersebut, maka indikator yang muncul meliputi infrastruktur berupa teknologi informasi, kehadiran instruktur, konten mata kuliah kewirausahaan, dukungan mentoring, dan student engagement, maka hipotesis kedua (H2) dirumuskan sebagai berikut:

\section{H2: E-learning berpengaruh terhadap minat berwirausaha.}

\section{Perceived Learning}

Persepsi belajar yang diterima, baik oleh mahasiswa mata kuliah kewirausahaan akan meningkatkan level kepuasan mereka atas kemampuan dirinya. Perceived learning terkait ilmu atau teori kewirausahaan yang diterima oleh mahasiswa diharapkan mampu meningkatkan atau memunculkan minat mahasiswa menjadi seorang wirausaha. Dengan tambahan ilmu yang diterima oleh seorang mahasiswa pada saat mengikuti proses pembelajaran kewirausahaan, maka mahasiswa tersebut diharapkan semakin tertarik untuk menjadi seorang wirausaha. Pembelajaran yang dilakukan secara online ini dapat dipengaruhi oleh perceived learning. Penelitian yang dilakukan oleh Tamimi dan Sebastianelli (2016) membuktikan bahwa perceived learning memberikan dampak positif terhadap minat berwirausaha pada diri seorang mahasiswa. Hal itu diartikan bahwa perceived learning dapat memperkuat atau memperlemah pengaruh e-learning terhadap minat berwirausaha. Berdasarkan argumentasi tersebut, maka hipotesis ketiga (H3) dirumuskan sebagai berikut:

\section{H3: Perceived learning memoderasi pengaruh e-learning terhadap minat berwira- usaha.}

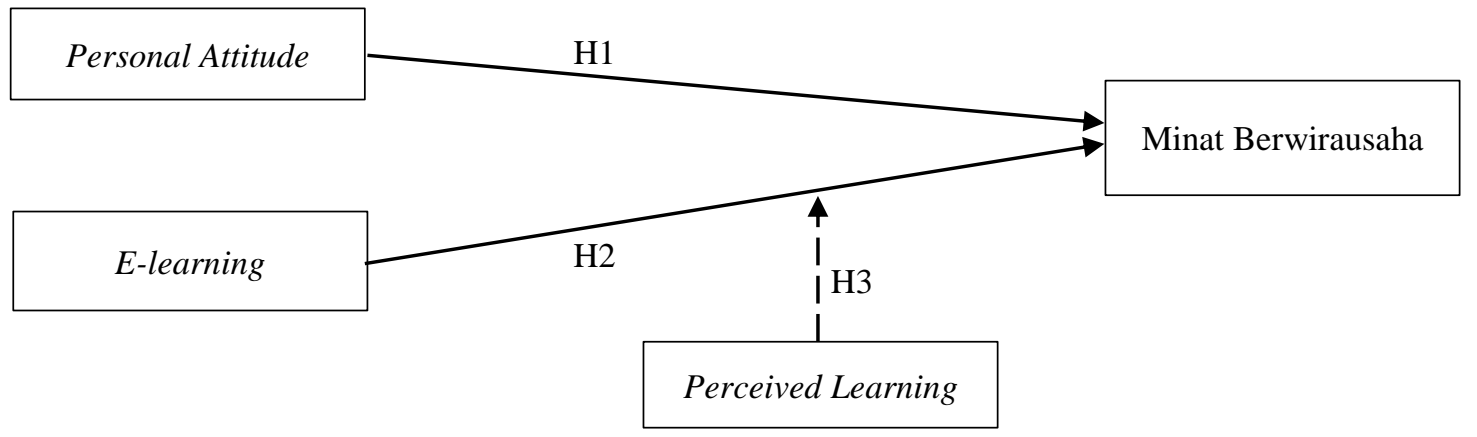

Gambar 1. Model Penelitian 


\section{Model Penelitian}

Model penelitian ini ditunjukkan oleh Gambar 1 yang menggambarkan hubungan antarvariabel dalam penelitian ini yang terdiri atas variabel independen, yaitu Personal Attitude dan E-learning, variabel dependen Minat Berwirausaha (entrepreneurial interest), dan variabel moderasi Perceived Learning.

\section{METODE PENELITIAN}

Model penelitian pada Gambar 1 mencakup satu variabel dependen (Minat Berwirausaha) dan dua variabel independen (Personal Attitude dan E-learning), serta satu variabel moderasi (Perceived Learning). Keempat variabel tersebut diuji berdasarkan investigasi empiris dan analisis statistik. Penelitian ini menggunakan data primer yang diperoleh melalui kuesioner online. Penggunaan instrumen kuesioner online dipilih dalam pengumpulan data penelitian ini, karena adanya kebijakan pembatasan kegiatan masyarakat akibat pandemi Covid-19. Kuesioner online terdiri atas lima bagian.

Bagian pertama berisi pertanyaan tentang informasi diskripsi responden yang meliputi jenis kelamin, usia, dan latar belakang keluarga. Bagian kedua sampai dengan kelima berisikan butir-butir pernyataan untuk mengukur keempat variabel yang diteliti meliputi variabel Personal Attitude, E-learning, Minat Berwirausaha, dan Perceived Learning (Tabel 1). Lima butir pernyataan digunakan sebagai indikator untuk mengukur variabel personal attitude (Linan \& Chen, 2009), dua belas butir pernyataan sebagai indikator $E$ learning (Ansong et al., 2016), empat butir pernyataan menjadi indikator untuk mengukur minat berwirausaha (Pihie, 2009), dan dua butir pernyataan sebagai indikator untuk mengukur perceived learning (Rovai, Wighting, Baker, \& Grooms, 2009). Pengukuran semua butir indikator tersebut menggunakan skala Likert dengan lima respon jawaban responden dari 1 yang berarti sangat tidak setuju sampai dengan 5 yang diartikan sangat setuju.

Sampel yang digunakan dalam penelitian ini adalah mahasiswa perguruan tinggi terpilih di Yogyakarta. Untuk maksud dan tujuan penelitian ini, empat perguruan tinggi yang menyelenggarakan kelas kewirausahaan di Yogyakarta dipilih sebagai obyek analisis dalam penelitian ini. Dari keempat perguruan tinggi terpilih tersebut, 90 responden berasal dari Sekolah Tinggi Ilmu Ekonomi YKPN Yogyakarta, 45 responden dari Universitas Atma Jaya Yogyakarta, 30 responden dari UPN Veteran Yogyakarta, dan 25 responden dari Universitas Widya Mataram Yogyakarta, sehingga jumlah sampel keseluruhan mencapai 190 responden. Pengambilan sampel menggunakan teknik purposive sampling. Kuesioner disampaikan kepada kepada responden yang mengikuti dua model pembelajaran, yaitu tatap muka dan daring. Dari hasil penyebaran kuesioner, penelitian ini berhasil mengumpulkan respon atau jawaban dari 190 responden. Pengumpulan data dilakukan melalui penyebaran kuesioner secara online dengan menggunakan Google form.

Pengolahan data dalam penelitian ini menggunakan Smart Partial Least Square (SmartPLS) 3.0. Model analisis yang digunakan dalam penelitian ini adalah model persamaan struktural (SEM). Dengan mengikuti pola SEM yang berbasis varian, maka pengolahan data penelitian ini dapat dilakukan secara bersamaan dengan pengujian model, pengukuran, maupun pengujian model strukturalnya. Penelitian ini menggunakan model analisis 
PLS, karena model ini merupakan metode alternatif penyelesaian model berjenjang yang kompleks, tidak memerlukan jumlah sampel yang banyak, tidak memerlukan asumsi normalitas, model mampu melibatkan penggunaan variabel terukur dan laten, serta model struktural yang memenuhi persyaratan model (Abdillah \& Hartono, 2015).

Tabel 1. Definisi Operasional Variabel Penelitian

\begin{tabular}{|c|c|c|c|c|}
\hline No & Variabel & Definisi Variabel & Indikator/Referensi & Skala \\
\hline 1 & Personal Attitude & $\begin{array}{l}\text { Personal attitude merupakan } \\
\text { sikap yang ditunjukkan oleh } \\
\text { seorang individu terkait sejauh } \\
\text { mana ia memegang penilaian } \\
\text { pribadi yang positif atau negatif } \\
\text { menjadi seorang pengusaha. }\end{array}$ & $\begin{array}{l}\text { - Keuntungan } \\
\text { - Karier } \\
\text { - Kesempatan } \\
\text { - Kepuasan } \\
\text { (Linan \& Chen, 2009) }\end{array}$ & Likert \\
\hline 2 & E-Learning & $\begin{array}{l}\text { Proses pembelajaran } e \text {-learning } \\
\text { mengacu pada penggunaan } \\
\text { komputer untuk menyajikan } \\
\text { latihan dan tutorial kepada } \\
\text { peserta didik dan melibatkan } \\
\text { mereka dalam dialog tentang } \\
\text { substansi pengajaran suatu } \\
\text { pelajaran (Zinn, 2003). }\end{array}$ & $\begin{array}{ll}\text { - } & \text { Pengaplikasian } \\
\text { - } & \text { Penyampaian } \\
\text { - } & \text { Penyelenggaraan } \\
\text { - } & \text { Pengetahuan } \\
\text { - } & \text { Konten pembelajaran } \\
\text { - } & \text { Reaksi mahasiswa } \\
\text { - } & \text { Keterlibatan } \\
& \text { mahasiswa } \\
\text { - } \quad \text { Masalah teknologi } \\
\text { - } \quad \text { Interaksi } \\
\text { - } \quad \text { Materi pembelajaran } \\
\text { - } \quad \text { Kemahaman } \\
\text { (Ansong et al., 2016) }\end{array}$ & Likert \\
\hline 3 & Minat Berwirausaha & $\begin{array}{l}\text { Minat berwirausaha merupakan } \\
\text { komitmen individu untuk } \\
\text { memulai usaha baru dan perlu } \\
\text { perhatian dalam memahami } \\
\text { proses pendirian wirausahanya } \\
\text { yang baru (Krueger, 1993). }\end{array}$ & $\begin{array}{l}\text { - } \quad \text { Ketertarikan } \\
\text { - } \quad \text { Kotivasi } \\
\text { - } \quad \text { Teinginan } \\
\text { (Pihie, 2009) }\end{array}$ & Likert \\
\hline 4 & Perceived Learning & $\begin{array}{l}\text { Perceived learning merupakan } \\
\text { persepsi belajar yang diterima } \\
\text { baik oleh mahasiswa } \\
\text { kewirausahaan untuk } \\
\text { meningkatkan level kepuasan } \\
\text { mahasiswa tersebut atas } \\
\text { kemampuan dirinya (Tamimi \& } \\
\text { Sebastianelli, 2016) }\end{array}$ & $\begin{array}{l}\text { - } \quad \text { Pemahaman } \\
\text { - } \quad \text { Penyampaian materi } \\
\text { (Rovai et al., 2009) }\end{array}$ & Likert \\
\hline
\end{tabular}

Sumber: Referensi terkait.

HASIL DAN PEMBAHASAN

Karakteristik Responden 
Data pada Tabel 2 menunjukkan bahwa mayoritas responden penelitian ini berjenis kelamin perempuan (64\%), mayoritas berasal dari program studi manajemen (86\%), dan mayoritas responden bukan berasal dari keluarga yang menjalankan usaha (65\%).

Tabel 2. Karakteristik Responden

\begin{tabular}{|c|c|c|c|c|c|c|c|c|}
\hline $\begin{array}{c}\text { Jenis } \\
\text { Kelamin }\end{array}$ & Jumlah & $\%$ & $\begin{array}{l}\text { Program } \\
\text { Studi }\end{array}$ & Jumlah & $\%$ & $\begin{array}{c}\text { Latar Belakang } \\
\text { Keluarga }\end{array}$ & Jumlah & $\%$ \\
\hline Perempuan & 121 & 64 & Manajemen & 163 & 86 & $\begin{array}{l}\text { Bukan Keluarga } \\
\text { Wirausaha }\end{array}$ & 123 & 65 \\
\hline \multirow[t]{3}{*}{ Laki-Laki } & 69 & 36 & Kewirausahaan & 13 & 7 & Keluarga Wirausaha & 67 & 35 \\
\hline & & & Ekonomi & 10 & 5 & & & \\
\hline & & & Akuntansi & 4 & 2 & & & \\
\hline Total & 190 & 100 & Total & 190 & 100 & Total & 190 & 100 \\
\hline
\end{tabular}

Sumber: Data primer diolah (2021).

\section{Uji Model Pengukuran}

Sebelum dilakukan analisis berdasarkan model persamaan struktural dengan SmartPLS 3.0, data penelitian ini dilakukan pengujian validitas dan reliabilitas untuk memastikan kecukupan dan ketepatan data guna analisis lebih lanjut. Data dalam penelitian ini dianalisis menggunakan software SmartPLS 3.0.

\section{Uji Validitas}

Berdasarkan hasil pengujian validitas yang ditunjukkan pada Tabel 3, nilai Average Variance Extracted (AVE) pada variabel e-learning sebesar 0,537, variabel minat berwirausaha sebesar 0,621, variabel personal attitude sebesar 0,666, dan variabel perceived learning sebesar 0,870 . Nilai AVE masing-masing variabel menunjukkan skor di atas 0,5 yang diartikan data pada semua variabel dinyatakan valid (Ghozali, 2014).

\begin{tabular}{|c|c|}
\hline Variabel & Nilai AVE \\
\hline Personal Attitude & 0,666 \\
\hline E-learning & 0,537 \\
\hline Perceived Learning & 0,870 \\
\hline Minat Berwirausaha & 0,621 \\
\hline
\end{tabular}

Sumber: Data primer diolah (2021).

\section{Uji Reliabilitas}

Pengujian reliabilitas pada Tabel 4 menunjukkan bahwa hasil uji komposit dan nilai Cronbach's alpha seluruh variabel yang diuji dalam penelitian ini dinyatakan reliabel. Hasil tersebut dikarenakan semua variabel laten bernilai composite reliability dan Cronbach's alpha di atas 0,7, sehingga data penelitian ini dinyatakan reliabel (Sharma, 2016). 
Tabel 4. Hasil Uji Composite Reliability dan Uji Cronbach's Alpha

\begin{tabular}{lccc}
\hline \multicolumn{1}{c}{ Variabel } & Composite Reliability & Cronbach's Alpha & Remark \\
\hline Personal Attitude & 0,907 & 0,870 & Reliable \\
\hline E-Learning & 0,932 & 0,923 & Reliable \\
\hline Perceived Learning & 0,930 & 0,850 & Reliable \\
\hline Minat Berwirausaha & 0,868 & 0,800 & Reliable \\
\hline
\end{tabular}

Sumber: Data primer diolah (2021).

\section{Uji Kelayakan Model}

Pendekatan nilai index Goodness of Fit (GoF) dilakukan untuk menguji kelayakan model dalam penelitian ini dengan cara mencari nilai $\mathrm{R}^{2}$ variabel dependen dan nilai Average Variance Extracted (AVE) pada setiap variabel laten (Tenenhaus, Amato, \& Vinzi, 2004). Hasil uji kelayakan model dapat dilihat pada Tabel 5.

Tabel 5. Hasil Uji Kelayakan Model

\begin{tabular}{|c|c|c|c|c|c|}
\hline Variabel Laten & Jumlah Indikator & AVE & Jumlah Terbobot & $\mathbf{R}^{2}$ & GoF \\
\hline Personal Attitude & 5 & 0,666 & 3,333 & & \\
\hline E-Learning & 12 & 0,537 & 6,444 & & \\
\hline Perceived Learning & 2 & 0,870 & 1,740 & & \\
\hline Minat Berwirausaha & 4 & 0,621 & 2,484 & 0,368 & \\
\hline Total & 23 & & 14,001 & 0,368 & \\
\hline Average & & & 0,608 & 0,368 & 0,473 \\
\hline
\end{tabular}

Sumber: Data primer diolah (2021).

Nilai GoF pada hasil uji kelayakan model menunjukkan nilai sebesar 0,473. Hasil ini menunjukkan bahwa 47,3\% variasi model dapat dijelaskan oleh data sampel penelitian ini. Nilai $\mathrm{R}^{2}$ sebesar 0,368 dapat diinterpretasikan bahwa variasi pada variabel minat berwirausaha mampu dijelaskan oleh variabel personal attitude, e-learning, dan perceived learning sebesar $36,8 \%$, sedangkan $63,2 \%$ dijelaskan oleh variabel lain di luar model penelitian ini.

Tabel 6. Hasil Pengujian Hipotesis

\begin{tabular}{lcccccl}
\hline & Hipotesis & $\begin{array}{c}\text { Original } \\
\text { Sample }\end{array}$ & St. Dev & $\begin{array}{c}\text { t- } \\
\text { statistics }\end{array}$ & p-values & Keterangan \\
\hline $\begin{array}{l}\text { Personal Attitude } \rightarrow \\
\text { Minat Berwirausaha }\end{array}$ & $\mathrm{H} 1$ & 0,432 & 0,126 & 3,430 & 0,001 & Positif, Signifikan \\
\hline $\begin{array}{l}\text { E-learning } \rightarrow \text { Minat } \\
\text { Berwirausaha }\end{array}$ & $\mathrm{H} 2$ & 0,073 & 0,070 & 1,037 & 0,300 & $\begin{array}{l}\text { Positif, Tidak } \\
\text { Signifikan }\end{array}$ \\
$\begin{array}{l}\text { Perceived Learning } \\
\text { memoderasi }\end{array}$ & $\mathrm{H} 3$ & $-0,011$ & $-0,018$ & 0,154 & 0,877 & $\begin{array}{l}\text { Negatif, Tidak } \\
\text { Signifikan }\end{array}$ \\
\hline
\end{tabular}

Sumber: Data primer diolah (2021). 


\section{Hasil Uji Hipotesis}

Hipotesis yang diajukan dalam penelitian ini diuji dengan menggunakan software SmartPLS 3.0 dan hasilnya disajikan pada Tabel 6. Hasil pengujian hipotesis pada Tabel 6 tersebut menunjukkan bahwa nilai $p$-values pada pengaruh personal attitude terhadap minat berwirausaha sebesar 0,001 yang berarti lebih kecil daripada 0,05. Hasil tersebut diartikan bahwa hipotesis kesatu (H1) diterima, yaitu personal attitude berpengaruh signifikan terhadap minat berwirausaha. Selanjutnya, nilai $p$-values pada pengaruh $e$-learning terhadap minat berwirausaha sebesar 0,278 yang berarti lebih besar daripada 0,05 . Hasil pengujian tersebut mengindikasikan bahwa e-learning tidak berpengaruh signifikan terhadap minat berwirausaha, sehingga hipotesis kedua $(\mathrm{H} 2)$ dalam penelitian ini ditolak. Nilai $p$-values untuk pengujian variabel perceived learning memoderasi pengaruh e-learning terhadap minat berwirausaha secara statistik tidak signifikan, karena nilai $p$-value sebesar 0,871 atau lebih besar daripada 0,05. Hasil ini menunjukkan bahwa variabel perceived learning tidak mampu memoderasi pengaruh e-learning terhadap minat berwirausaha, sehingga hipotesis ketiga (H3) ditolak.

\section{Pembahasan}

\section{Personal Attitude Berpengaruh Positif terhadap Minat Berwirausaha}

Hasil pengujian menunjukkan bahwa $\mathrm{H} 1$ diterima yang diartikan bahwa personal attitude berpengaruh signifikan terhadap minat berwirausaha. Signifikansi pada pengujian hipotesis ini dapat diartikan bahwa semakin baik sikap seseorang, maka minat berwirausaha akan semakin meningkat. Perilaku muncul dari kebiasaan seseorang, sedangkan kebiasaan tercipta karena mereka memiliki kebutuhan. Kebutuhan inilah yang mendorong seseorang memiliki motivasi tertentu. Sikap baik yang muncul pada orang ini akan terbawa ke depan dalam menjalankan bisnis. Bisnis yang didasarkan pada sikap dan minat yang baik akan berjalan dengan lancar dan diharapkan dapat bertahan lama (Ferreira et al., 2012). Temuan ini membuktikan bahwa personal attitude berpengaruh positif terhadap minat berwirausaha. Mendasari temuan tersebut, Ajzen dan Fishbein (2005) dalam teorinya menyebutkan bahwa sikap diartikan sebagai evaluasi positif atau negatif individu terhadap obyek, orang, lembaga, peristiwa, perilaku, atau minat tertentu.

\section{E-Learning Tidak Berpengaruh terhadap Minat Berwirausaha}

Mason dan Rennie (2010) berpendapat bahwa sistem pembelajaran elektronik memiliki definisi pembelajaran dan pengajaran berbantuan komputer yang berfokus pada konten, komunikasi, dan teknologi. Kondisi pandemi Covid-19 yang terjadi saat ini membutuhkan semua e-learning system. Sistem e-learning diharapkan dapat mendukung penyampaian materi secara lebih efektif dan efisien di tengah-tengah pandemi Covid-19. Namun, berdasarkan hasil analisis penelitian ini justru menunjukkan bahwa e-learning tidak berpengaruh signifikan terhadap minat berwirausaha. Hasil analisis menunjukkan bahwa H2 ditolak, sehingga e-learning tidak berpengaruh signifikan terhadap minat berwirausaha para mahasiswa yang menempuh mata kuliah kewirausahaan. Penelitian yang dilakukan oleh Batol, Anam, dan Zahra (2011) menyimpulkan bahwa jika seseorang merasa percaya diri dan meyakini bahwa suatu sistem bermanfaat, maka ia akan menggunakan- 
nya. Sebaliknya, jika ia merasa yakin dan percaya bahwa sistem informasi kurang bermanfaat, maka ia tidak akan menggunakannya.

Sistem pembelajaran $e$-learning yang diterapkan saat ini berdampak pada penerimaan pembelajaran pada setiap mahasiswa, termasuk penerimaan pembelajaran mata kuliah kewirausahaan. Berdasarkan pengujian pada hipotesis kedua, mahasiswa meyakini bahwa mata kuliah kewirausahaan tidak harus dilakukan secara offline, tetapi perkuliahan tersebut dapat dilakukan secara online juga. Penyampaian materi kuliah kewirausahaan melalui media online terbukti tidak mengubah minat berwirausaha pada mahasiswa. Temuan ini menunjukkan bahwa mahasiswa yang memiliki minat kuat berwirausaha, maka ia tidak akan terpengaruh oleh proses pembelajaran yang tidak atau kurang memberikan materi praktik berwirausaha. Pada kenyataannya, bisnis online berkembang pesat dan masyarakat semakin nyaman melakukan transaksi secara online. Intensitas tersebut semakin tinggi di era pandemi Covid-19 yang mengarahkan masyarakat untuk tetap bekerja dan belajar di rumah, sehingga melakukan transaksi secara online lebih diminati oleh konsumen.

\section{Perceived Learning Tidak Mampu Memoderasi Hubungan antara E-Learning dan Minat Berwirausaha}

Hasil pengujian hipotesis ketiga (H3) pada moderasi perceived learning antara $e$ learning dan minat berwirausaha menunjukkan bahwa variabel perceived learning tidak mampu memoderasi pengaruh e-learning terhadap minat berwirausaha. Temuan ini menunjukkan bahwa proses yang dialami seseorang ketika menerima atau mengikuti pembelajaran e-learning dalam mata kuliah kewirausahaan selama pandemi Covid-19 tidak mempengaruhi minat mahasiswa menjadi seorang wirausaha meskipun dimoderasi oleh perceived learning. Temuan ini didukung oleh penelitian Yaman dan Muhlis (2020) yang membuktikan bahwa sebagian besar mahasiswa merasa sulit menerima pembelajaran pada kelas online yang berlangsung selama pandemi Covid-19 saat ini. Kondisi tersebut disebabkan karena masalah teknis, keterbatasan waktu, dan kesulitan memahami tujuan kelas online. Hasil ini menunjukkan bahwa perceived learning tidak mampu memperkuat atau memperlemah pengaruh e-learning terhadap minat berwirausaha mahasiswa.

\section{KESIMPULAN DAN SARAN}

\section{Kesimpulan}

Hasil penelitian ini mendukung kedua hipotesis yang diajukan yaitu, personal attitude berdampak positif terhadap minat berwirausaha dan e-learning tidak berpengaruh terhadap minat berwirausaha. Temuan pada penelitian ini mengungkapkan bahwa personal attitude berdampak positif terhadap minat berwirausaha, artinya bahwa semakin baik sikap seseorang, maka semakin besar minatnya menjadi seorang wirausahawan. Sikap baik individu akan terbawa nantinya dalam mengelola dan mengembangkan sebuah bisnis. Penelitian ini juga membuktikan bahwa e-learning tidak berpengaruh terhadap minat berwirausaha. Artinya, mata kuliah kewirausahaan tidak harus dilakukan secara offline, tetapi kuliah tersebut dapat dilakukan secara online juga. Namun, cara penyampaian materi pada mata kuliah kewirausahaan antara online dan offline terbukti tidak mengubah minat berwirausaha mahasiswa Temuan penelitian ini juga membuktikan bahwa variabel 
perceived learning ternyata tidak mampu memoderasi hubungan antara $e$-learning terhadap minat berwirausaha. Jika seorang mahasiswa telah memiliki minat kuat berwirausaha, maka ia akan menerima pembelajaran kewirausahaan dan mengikutinya dengan sepenuh hati dan materinya akan lebih mudah diterima. Berdasarkan temuan-temuan ini, maka hasil penelitian ini menunjukkan bahwa pada era pandemi Covid-19 terjadi perubahan proses pembelajaran mata kuliah kewirausahaan. Namun, kondisi tersebut tidak akan mengubah minat berwirausaha mahasiswa.

\section{Saran}

Keterbatasan penelitian ini adalah jumlah sampel yang digunakan masih terbatas untuk mendapatkan hasil yang lebih optimal. Penelitian selanjutnya dapat menambah jumlah sampel yang digunakan. Hasil pengujian dalam penelitian ini menunjukkan bahwa variabel perceived learning masih belum mampu memoderasi hubungan e-learning terhadap minat berwirausaha, sehingga penelitian selanjutnya dapat menambahkan atau mengganti variabel moderasi untuk mendapatkan faktor yang dapat menentukan pengaruh $e$ learning terhadap minat berwirausaha.

\section{DAFTAR REFERENSI}

Abdillah, W., \& Hartono, J. (2015). Partial Least Square (PLS) Alternatif SEM dalam Penelitian Bisnis. Yogyakarta: Penerbit Andi.

Ajzen, I., \& Fishbein, M. (2005). The Influence of Attitude on Behavior. The Handbook of Attitudes. New Jersey: Lawrence Erlbaum Associates.

Batol, S., Anam, A., \& Zahra, N. (2011). Cheating Behavior Among Undergraduate. International Journal of Business and Social Science, 2(3), 246-254.

Ansong, E., Boateng, S. L., Boateng, R., \& Effah, J. (2016). Determinants of E-Learning Adoption in Universities: Evidence from a Developing Country. 49th Hawaii International Conference on System Sciences, 21-30.

Asih, W. M., Kamil, I., \& Indrapriyatna, A. S. (2020). Peran Pendidikan Kewirausahaan terhadap Perilaku Inovatif Mahasiswa dalam Menghadapi Revolusi Industri 4.0. Jurnal Manajemen, Kepemimpinan, dan Supervisi Pendidikan, 5(1), 31-38.

Bird, B. (1988). Implementing Entrepreneurial Ideas: The Case for Intention. The Academy of Management Review, 13(3), 442-453.

CNN Indonesia (2020). 98 Persen Kampus PJJ Daring, Kemdikbud Klaim Mahasiswa Siap. Peristiwa Nasional, 3 September. Retrieved April 25, 2021, from https://www.cnnindonesia.com/nasional/20200903012249-20-542198/98-persenkampus-pjj-daring-kemdikbud-klaim-mahasiswa-siap.

Ferreira, J. J., Raposo, M. L., Rodrigues, R. G., Dinis, A., \& do Paco, A. (2012). A Model of Entrepreneurial Intention: An Application of the Psychological and Behavioral Approaches. Journal of Small Business and Enterprise Development, 19(3), 424-440.

Fiet, J. O. (2002). The Systematic Search for Entrepreneurial Discoveries. Westport, CT: Praeger. 
Fikri, C. (2021). Tiga Dampak Pandemi Covid-19 bagi Perekonomian Nasional. Berita Satu, 5 Februari. Retrieved April 1, 2021 from https://www.beritasatu.com/ekonomi/728997/tiga-dampak-pandemi-covid19-bagiperekonomian-nasional.

Ghozali, I. (2014). Structural Equation Modeling, Metode Alternatif dengan Partial Least Square (PLS). Semarang: Badan Penerbit Universitas Diponegoro.

Ismail, V., \& Zain, E. (2008). Peranan Sikap, Norma Subjektif, dan Perceived Behavioral Control terhadap Intensi Pelajar SLTA untuk Memilih Fakultas Ekonomi. Jurnal Ekonomi dan Bisnis, 5(3), 237-257.

Krueger, N. F. (1993). The Impact of Prior Entrepreneurial Exposure on Perceptions of New Venture Feasibility and Desirability. Entrepreneurship Theory and Practice, 18(1), 5-21. https://doi.org/10.1177/104225879301800101.

Lee, S. H., \& Wong, P. K. (2004). An Exploratory Study of Technopreneurial Intentions: A Career Anchor Perspective. Journal of Business Venturing, 19(1), 7-28.

Linan, F., \& Chen, Y.-W. (2009). Development and Cross-Cultural Application of a Specific Instrument to Measure Entrepreneurial Intentions. Entrepreneurship Theory and Practice, 33(3), 593-617. https://doi.org/10.1111/j.1540-6520.2009.00318.x.

Mason, R., \& Rennie, F. (2010). E-Learning: Panduan Lengkap Memahami Dunia Digital dan Internet. Yogyakarta: Pustaka Baca!

Mustofa, M. (2014). Entrepreneurship Syariah (Menggali Nilai-Nilai Dasar Manajemen Bisnis Rasulullah). Al-Mizan, 9(1), 29-46.

Yaman, N., \& Muhlis, M. (2020). Students' Social Presence and Perceived Learning Toward Cross-Cultural Understanding Course in Online Classroom (An Evaluating of Learning Process During Pandemic Coronavirus). Elite: English and Literature Journal, 7(1), 61-73.

Pihie, Z. A. L. (2009). Entrepreneurship As a Career Choice: An Analysis of Entrepreneurial Self-Efficacy and Intention of University Students. European Journal of Social Sciences, 9(2), 338-349.

Popescu, C-A., \& Simion, P. C. (2012). Entrepreneurship Education and E-Learning: A Perfect Match. Journal of Electrical and Electronics Engineering, 5(1), 203-206.

Rifa'i, A., \& Nugraha, T. (2019). Rencana Strategi dalam Menerapkan Pendidikan Kewirausahaan di Perguruan Tinggi melalui Proses Pembelajaran yang Berkelanjutan. (Studi Kasus pada Universitas Banten Jaya Kota Serang-Banten). Jurnal Manajemen dan Bisnis, 1(01), 71-90.

Rovai, A. P., Wighting, M. J., Baker, J. D., \& Grooms, L. D. (2009). Development of an Instrument to Measure Perceived Cognitive, Affective, and Psychomotor Learning in Traditional and Virtual Classroom Higher Education Settings. The Internet and Higher Education, 12(1), 7-13.

Seagal, G., Borgia, D., \& Schoenfeld, J. (2005). The Motivation to Become an Entrepreneur. International Journal of Entrepreneurial Behavior \& Research, 11(1), $42-57$. 
Shane, S., Locke, E. A., \& Collins, C. J. (2003). Entrepreneurial Motivation. Human Resource Management Review, 13(2), 257-279.

Sharma, B. (2016). A Focus on Reliability in Developmental Research through Cronbach's Alpha among Medical, Dental and Paramedical Professionals. Asian Pacific Journal of Health Sciences, 3(4), 271-278.

Suryana, Y., \& Bayu, K. (2014). Kewirausahaan: Pendekatan, Karakteristik Wirausahawan Sukses. Jakarta: Kencana.

Tamimi, N., \& Sebastianelli, R. (2016). How E-Tailing Attributes Affect Perceived Quality: The Potential Impact of Customer Demographics and Online Behaviors. The TQM Journal, 28(4), 547-560.

Tenenhaus, M., Amato, S., \& Vinzi, V. E. (2004). A Global Goodness-of-Fit Index for PLS Structural Equation Modelling. In Proceeding of the XLII SIS Scientific Meeting, 1(2), 739-742.

Thompson, P., \& Randall, B. (2001). Can E-Learning Spur Creativity, Innovation and Entrepreneurship? Educational Media International, 38(4), 289-292.

Tong, X. F., Tong, D. Y. K., \& Loy, L. C. (2011). Factors Influencing Entrepreneurial Intention Among University Students. International Journal of Social Sciences and Humanity Studies, 3(1), 487-496.

Wibowo, A. (2011). Pendidikan Kewirausahaan (Konsep dan Strategi). Yogyakarta: Pustaka Pelajar.

Zinn, K. (2003). Computer-Assisted Learning and Teaching. In Encyclopedia of Computer Science. Chichester, UK: John Wiley and Sons, Ltd. 